Letter to the Editor

\title{
Marked shrinkage of amyloid lymphadenopathy after an intensive chemotherapy in a patient with IgM-associated AL amyloidosis
}

Ko-ichi Tazawa, Nagaaki Katoh, Yasuhiro Shimojima, Masayuki Matsuda, Shu-ichi Ikeda

Department of Medicine (Neurology and Rheumatologoy), Shinshu University School of Medicine, 3-1-1 Asahi, Matsumoto 390-8621, Japan

Key words: IgM-associated AL amyloidosis, plasma cell dyscrasia, lymphadenopathy, chemotherapy, regression of amyloid

Running title: Chemotherapeutic effects on AL amyloid lymphadenopathy

Abbreviations: VAD: vincristine, doxorubicin and dexamethasone, HDM: high-dose melphalan, SCT: autologous stem cell transplantation, CT: computed tomography, FLCs: free light chains

Correspondence: Dr. Masayuki Matsuda, Department of Medicine (Neurology and Rheumatology), Shinshu University School of Medicine, 3-1-1 Asahi, Matsumoto 390-8621, Japan

Tel: $+81-263-37-2673$

Fax: $+81-263-37-3427$

e-mail: matsuma@shinshu-u.ac.jp 


\begin{abstract}
A male patient with primary AL amyloidosis who had been suffering from systemic lymphadenopathy with IgM $\kappa$-type M-proteinemia received 2 courses of VAD and high-dose melphalan with in vivo elimination of $\mathrm{CD} 20^{+}$cells using rituximab followed by autologous peripheral blood stem cell transplantation. Four years after complete hematological remission he showed marked reduction in size of the amyloid-laden lymph nodes. Deposits of AL amyloid may regress from the tissue if the chemotherapy succeeds in persistent inhibition of the production of an amyloidogenic immunoglobulin light chain.
\end{abstract}


Primary systemic AL amyloidosis is caused by plasma cell dyscrasia and produces dysfunction of many visceral organs, the heart and kidney being most frequently involved [1]. Intensive chemotherapy, such as high-dose melphalan followed by autologous stem cell transplantation (HDM/SCT), has been recently reported to improve the function of the affected organs if complete hematological remission is achieved $[2,3]$. Nevertheless, it remains unclear whether or not AL amyloid deposits regress from the tissue after the disappearance of M-protein in serum or urine. In this report we describe an IgM-associated AL amyloidosis patient with systemic lymphadenopathy who was treated with vincristine, doxorubicin and dexamethasone (VAD), and the following HDM/SCT. The patient showed remarkable reduction in size of swollen lymph nodes 4 years after this intensive chemotherapy.

\section{Case report}

A 49-year-old man developed progressive systemic lymphadenopathy, particularly in the neck and axilla (Fig 1-A). Computed tomography (CT) showed enlarged lymph nodes also in bilateral inguinal regions, but not in either the mediastinum or retroperitoneum. On the basis of IgMк-type M-protein in serum, clonal expansion of $\mathrm{CD} 20^{+} \kappa^{+}$cells in bone marrow and histopathology of lymph nodes showing massive deposition of Aא-immunoreactive amyloid (Fig. 2), he was diagnosed as having primary AL amylodosis as reported previously [4]. The patient showed no abnormal findings in laboratory data suggestive of visceral organ involvement or amyloid deposition in other biopsied tissues, including the gastroduodenal mucosa and abdominal fat. Serum free light chains (FLCs) were $25.7 \mathrm{mg} / \mathrm{L}$ in $\kappa$ (normal: 3.3-19.4 $\mathrm{mg} / \mathrm{L}$ ) and $11.6 \mathrm{mg} / \mathrm{L}$ in $\lambda$ (normal: $5.7-26.3 \mathrm{mg} / \mathrm{L}$ ), and the $\kappa / \lambda$ ratio was 2.18 (normal: 0.26-1.65). At age 50 he achieved complete hematological remission after 2 courses of VAD and the following HDM/SCT according to our protocol [5] and in vivo elimination of $\mathrm{CD} 20^{+}$cells using rituximab. Serum IgM decreased to normal range (1,235 to 137 $\mathrm{mg} / \mathrm{dL}$, normal: $35-220 \mathrm{mg} / \mathrm{dL}$ ) in conjunction with disappearance of M-protein on immunofixation and normalization of amyloidogenic $\kappa$-type FLCs $(11.5 \mathrm{mg} / \mathrm{L})$ and the $\kappa / \lambda$ ratio (0.99). Lymph nodes gradually became smaller during the follow-up observation in the outpatient clinic. Serum IgM and FLC have remained in the normal range with negative results of serum $M$-protein on immunofixation for 4 years since achievement of complete hematological remission. At age 54 he appeared healthy and showed marked reduction in size of affected lymph nodes on CT (Fig. 1-B).

\section{Discussion}

Removal of amyloid fibrils from the affected tissues using chemotherapy is difficult and thus, radical treatments for underlying disorders or pathology producing amyloid precursor proteins have been employed for systemic amyloidosis. It has been recently noted that post-treatment regression of amyloid deposits certainly occurs in patients with some forms of systemic amyloidosis [6-9]. In primary systemic AL amyloidosis it has been shown that malfunction of visceral organs, including heart and kidney, remains stable and/or often improves after intensive chemotherapies targeting plasma cell dyscrasia [2,3]. However, regression of AL amyloid deposits after these treatments remains controversial: some reports demonstrated a decrease in AL amyloid on the basis of histopathology of abdominal fat tissue or radiolabelled SAP scintigraphy 
[10, 11], while in others serial renal biopsies failed to show histolopathological regression of AL amyloid deposits even after improvement of renal function $[12,13]$. Twenty to $30 \%$ of the patients with IgM-associated AL amyoidosis show systemic lymphadenopathy as seen in the present patient, but no improvement after the chemotherapy has been so far reported [14, 15]. The present patient showed marked reduction in size of involved lymph nodes on CT images 4 years after the intensive chemotherapy in conjunction with persistently negative M-protein in serum and normalization of serum FLCs. Considering that massive accumulation of AL amyloid caused remarkable lymphadenoapthy before chemotherapy, cessation of the supply of an amyloid precursor protein may have led to regression of these amyloid deposits in the affected lymph nodes of this patient. The mechanisms by which amyloid is mobilized and cleared from the affected tissues are not known in any types of systemic amyloidosis.

\section{Acknowledgement}

This work was supported by a grant from the Intractable Disease Division, the Ministry of Health and Welfare, Amyloidosis Research Committee in Japan. 


\section{References}

1. Kyle RA, Gertz MA. Primary systemic amyloidosis. Clinical and laboratory features in 474 cases. Semin Hematol 1995; 32: 45-59.

2. Skinner M, Sanchorawala V, Seldin DC, Dember LM, Falk RH, Berk JL, Anderson JJ, O’Hara C, Finn KT, Libbey CA, Wiesman J, Quillen K, Swan N, Wright DG. High-dose melphalan and autologous stem-cell transplantation in patients with AL amyloidosis: an 8-year study. Ann Intern Med 2004; 140: 85-93.

3. Sanchorawala V, Seldin DC. An overview of high-dose melphalan and stem cell transplantation in the treatment of AL amyloidosis. Amyloid: J Protein Folding Disord 2007; 14: 261-269.

4. Matsuda M, Gono T, Shimojima Y, Yoshida T, Katoh N, Hoshii Y, Yamada T, Ikeda S. AL amyloidosis manifesting as systemic lymphadenopathy. Amyloid: J Protein Folding Disord 2008; 15: 117-124.

5. Gono T, Matsuda M, Shimojima Y, Ishii W, Koyama J, Sakashita K, Koike K, Hoshii Y, Ikeda S. VAD with or without subsequent high-dose melphalan followed by autologous stem cell support in AL amyloidosis: Japanese experience and criteria for patient selection. Amyloid: J Protein Folding Disord 2004; 11: 245-256.

6. Gillmore JD, Lovat LB, Persey MR, Pepys MB, Hawkins PN. Amyloid load and clinical outcome in AA amyloidosis in relation to circulating concentration of serum amyloid A protein. Lancet 2001; 358: 24-29.

7. Verbrugghe W, Maes BD, Knockaert DC. Localized plasma-cell type Castleman's disease and AA-amyloidosis cured by resection. A case report and review of literature. Acta Clin Belg 2005; 60: 22-27.

8. Shimojima Y, Takei Y, Tasawa K, Gono T, Fushimi T, Matsuda M, Hoshii Y, Ikeda S. Histopathological regression of systemic AA amyloidosis after surgical treatment of a localized Castleman's disease. Amyloid: J Protein Folding Disord 2006; 13: 184-186.

9. Tsuchiya A, Yazaki M, Kametani F, Takei Y, Ikeda S. Marked regression of abdominal fat amyloid in patients with familial amyloid polyneuropathy during long-term follow-up after liver transplantation. Liver Transpl 2008; 14: 563-570.

10. van Buren M, Hene RJ, Verdonck LF, Verzijbergen FJ, Lokhorst HM. Clinical remission after syngeneic bone marrow transplantation in a patient with $\mathrm{AL}$ amyloidosis. Ann Intern Med 1995; 122: 508-510.

11. van Gameren II, Hazenberg BPC, Jager PL, Smit JW, Vellenga E. AL amyloidosis treated with induction chemotherapy with VAD followed by high dose melphalan and autologous stem cell transplantation. Amyloid: J Protein Folding Disord 2002; 9: $165-174$.

12. Sezer O, Schmid P, Schweigert M, Heider U, Eucker J, Harder H, Sinha P, Radtke H, Possinger K. Rapid reversal of nephritic syndrome due to primary systemic AL amyloidosis after VAD and subsequent high-dose chemotherapy with autologous stem cell support. Bone Marrow Transplant 1999; 23: 967-969.

13. Zeier M, Perz B, J, Linke RP, Donini U, Waldherr R, Andrassy K, Ho AD, Goldschmidt H. No regression of renal AL amyloidosis in monoclonal gammopathy after successful autologous blood cell transplantation and significant clinical 
improvement. Nephrol Dial Transplant 2003; 18: 2644-2647.

14. Wechalekar AD, Lachmann HJ, GoodmanHJB, Bradwell A, Hawkins PN, Gillmore JD. AL amyloidosis associated with $\operatorname{IgM}$ paraproteinemia: clinical profile and treatment outcome. Blood 2008; 112: 4009-4016.

15. Terrier B, Jaccard A, Harousseau JL, Delarue R, Tournilhac O, Hunault-Berger M, Hamidou M, Dantal J, Bernard M, Grosbois B, Morel P, Coiteux V, Gisserot O, Rodon P, Hot A, Elie C, Leblond V, Fermand JP, Fakhouri F. The clinical spectrum of IgM-related amyloidosis: a French nationwide retrospective study of 72 patients. Medicine (Baltimore) 2008; 87: 99-109. 


\section{Figure legends}

Figure 1: CT images of lymphadenopathy before and after chemotherapy.

A: At admission enlarged lymph nodes with positive contrast enhancement (indicated by arrows) are seen in the neck and axilla. B: 4 years after treatment they showed marked shrinkage, especially in left axillar area.

Figure 2: Histopathology of the biopsied cervical lymphnode.

Congo red staining shows extensive deposition of amyloid (A), which has characteristic apple-green appearance under polarized view (B). 

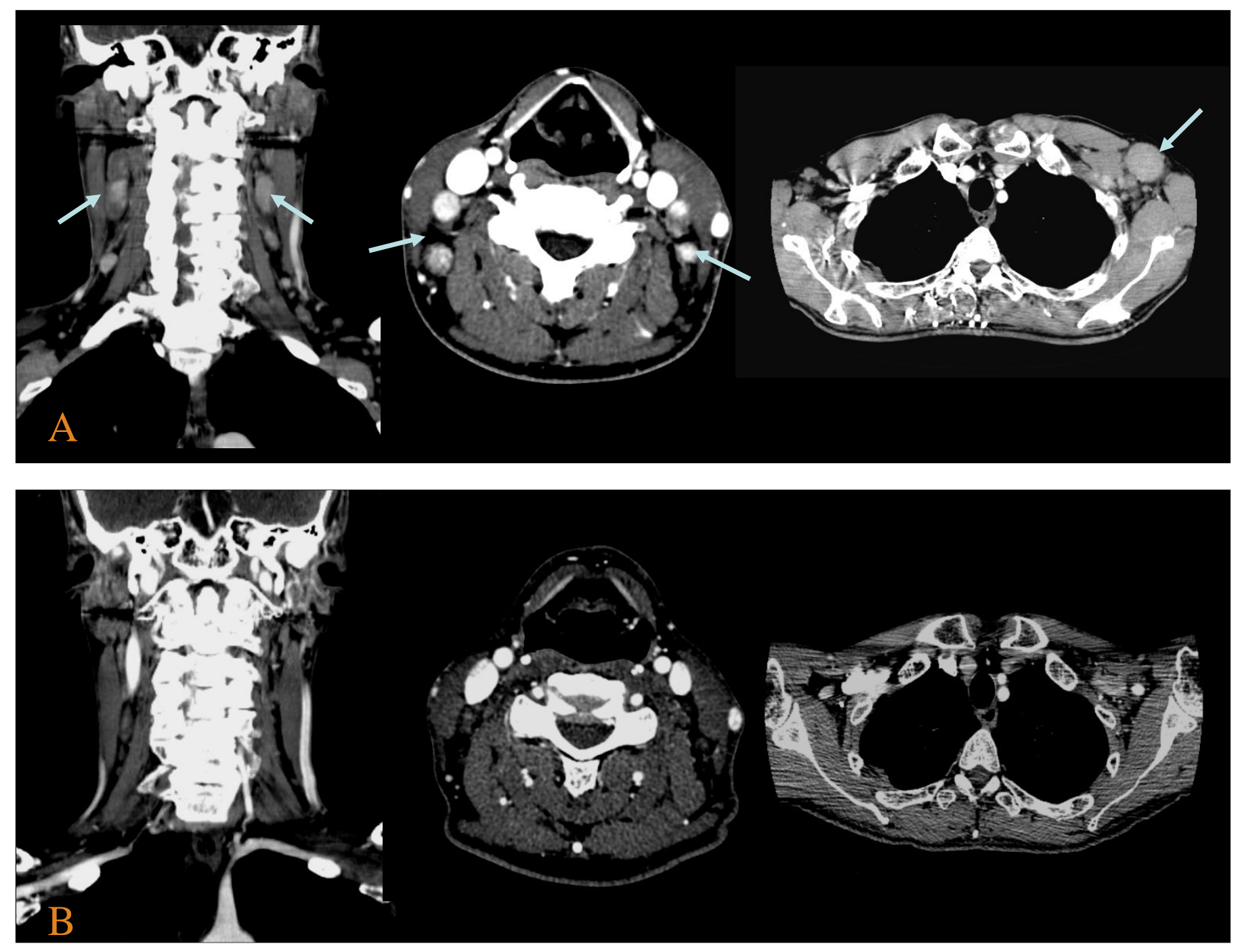

Figure 1 


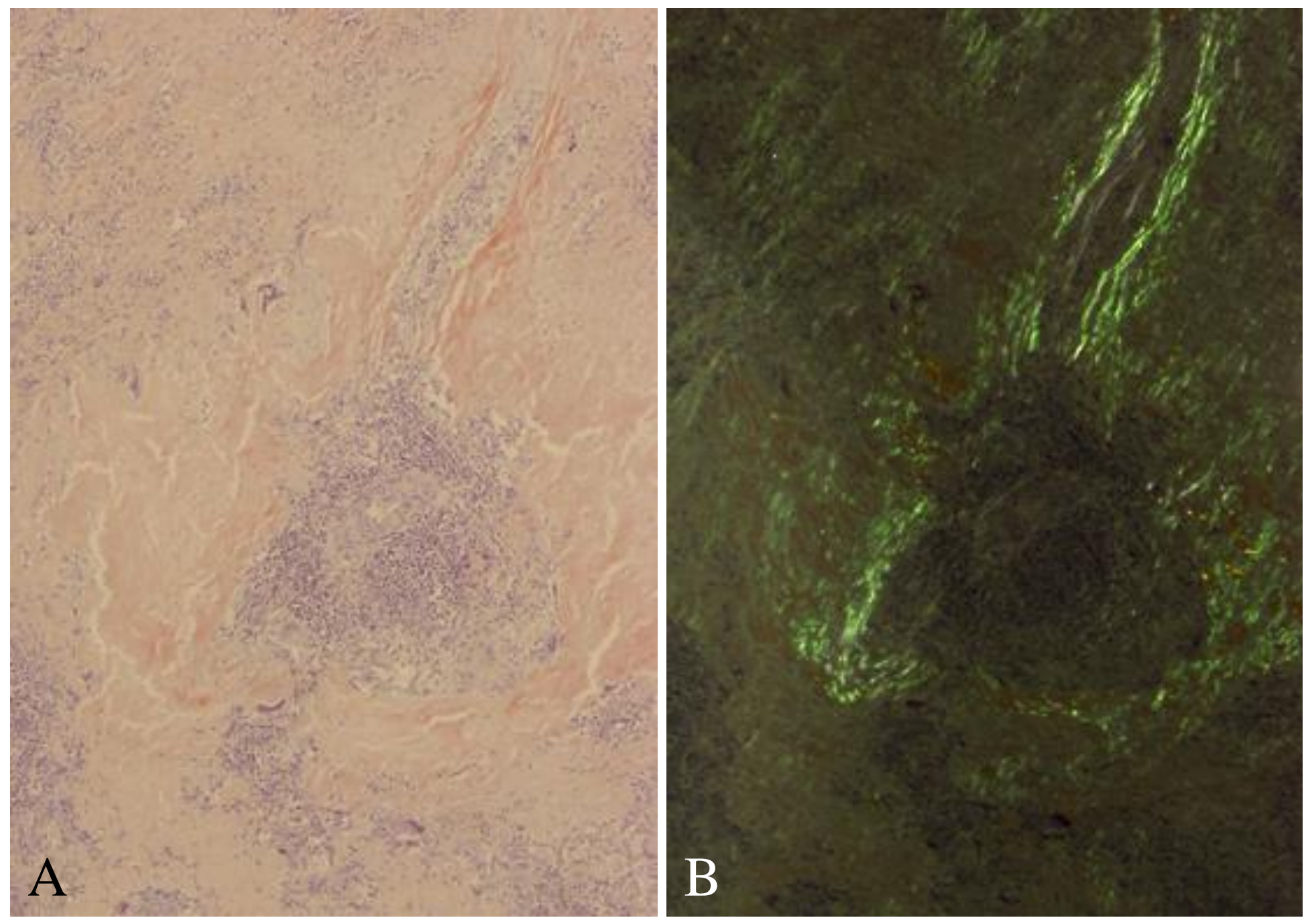

Figure 2 